\title{
Genotoxicity of lapachol evaluated by wing spot test of Drosophila melanogaster
}

\author{
Wender Ferreira $\operatorname{Costa}^{1}$, Alaide Braga de Oliveira ${ }^{2}$ and Júlio César Nepomuceno ${ }^{1,3}$ \\ ${ }^{1}$ Instituto de Genética e Bioquímica, Universidade Federal de Uberlândia, Uberlândia, MG, Brazil. \\ ${ }^{2}$ Departamento de Produtos Farmacêuticos, Faculdade de Farmácia, \\ Universidade Federal de Minas Gerais, Belo Horizonte, MG, Brazil. \\ ${ }^{3}$ Laboratório de Citogenética e Mutagênese, Centro Universitário de Patos de Minas, Patos de Minas, \\ $M G$, Brazil.
}

\begin{abstract}
This study investigated the genotoxicity of Lapachol (LAP) evaluated by wing spot test of Drosophila melanogaster in the descendants from standard (ST) and high bioactivation (HB) crosses. This assay detects the loss of heterozygosity of marker genes expressed phenotypically on the fly's wings. Drosophila has extensive genetic homology to mammals, which makes it a suitable model organism for genotoxic investigations. Three-day-old larvae from ST crosses (females $\mathrm{flr}^{3} / \mathrm{TM} 3, B d^{s} \mathrm{x}$ males $\mathrm{mwh} / \mathrm{mwh}$ ), with basal levels of the cytochrome P450 and larvae of high metabolic bioactivity capacity (HB cross) (females ORR; $f / r^{3} / T M 3, B d^{\beta}$ x males $m w h / m w h$ ), were used. The results showed that LAP is a promutagen, exhibiting genotoxic activity in larvae from the HB cross. In other words, an increase in the frequency of spots is exclusive of individuals with a high level of the cytochrome P450. The results also indicate that recombinogenicity is the main genotoxic event induced by LAP.
\end{abstract}

Key words: Drosophila melanogaster, SMART, lapachol, doxorubicin, cytochrome P450.

Received: September 3, 2009; Accepted: April 5, 2010.

Approximately two-thirds of the biological diversity worldwide occurs in tropical zones, mainly in developing countries, especially in Brazil with several different biomes (Vieira, 1999). The Cerrado, the second largest ecological domain, covers approximately $25 \%$ of the total surface area, with a continuous herbaceous stratum joined to an arboreal one, with variable density of woody species, and Around 220 of those species reportedly used in traditional medicine (Vieira and Martins, 1998).

Lapachol (LAP), 4-hydroxy-3-(3-methylbut-2enyl)naphthalene-1,2-dione, is a naphthoquinone found in many vegetable species of the Bignoniaceae family, specifically those of the genus Tabebuia (Tabebuia aurea, Tabebuia impetiginosa, Tabebuia ochracea) from the Cerrado. It is endowed with antimicrobial qualities active in combating bacterial, fungal and virus infections, as well as, and more importantly, cancer (Fonseca et al., 2004; Castellanos et al., 2009). This quinone showed significant in vivo anti-tumor activity in several early mouse models (Rao et al.,1968), since then progressing to clinical trials by the National Cancer Institute (NCI) in the 1970's. How-

Send correspondence to Júlio César Nepomuceno. Instituto de Genética e Bioquímica, Universidade Federal de Uberlândia, Av. Para 1720, 38400-902 Uberlândia, MG, Brazil. E-mail: nepomuceno@ufu.br. ever, in 1974, the NCI concluded that the high concentrations required for efficient chemotherapy in human cancer treatment, unfortunately also gave rise to extremely toxic side-effects, thereby justifying its rejection (Suffness and Douros, 1980; Castellanos et al., 2009). Notwithstanding, recent results have shown that lapachol, isolapachol and its acetylderivative are significantly active against Biomphalaria glabrata, the intermediate host of Schistosoma mansoni (Santos et al., 2000; Lima et al., 2002). According to Lima et al. (2004), antileishmanial activity was found to be efficient against certain viral strains including herpes virus Types I and II (Silva et al., 2002). LAP proved to be a vitamin K-antagonist antigen, thus possibly targeting vitamin K-dependent reactions (Dinnen and Ebisuzaki, 1997), besides also being bio-activated by P450 reductase to reactive species which promote DNA scission, through redox cycling with generation of free radicals (Kumagai et al., 1997). The enzyme responsible for bioactivating lapachol, thereby leading to the generation of ROS capable of causing DNA damage, was unknown. An immunoinhibition study with antibodies against cytochrome $\mathrm{P} 450$ reductase (P450R), revealed that $\mathrm{P} 450 \mathrm{R}$ was a predominant enzyme in catalyzing the one-electron reduction of lapachol (Kumagai et al., 1997). 
Generation of reactive oxygen species, superoxide anion radical and hydroxyl radical during the metabolism of LAP by P450 reductase, was confirmed by acetylated cytochrome reduction assay in the absence and presence of $\mathrm{Cu}, \mathrm{Zn}$-SOD (Superoxide Dismutase), and electron spin resonance (ESR) studies (Kumagai et al., 1997).

Certain synthetic derivatives of lapachol, such as mono-(arylimines)-o quinones derived from $\beta$-lapachone, also inhibit the activity of the enzyme topoisomerases (Esteves-Souza et al., 2007). DNA supercoiling is a precisely regulated process that influences DNA replication, transcription and packaging. The DNA topoisomerases are enzymes that modulate the topological state of DNA.

The wing somatic mutation and recombination test (SMART), when using Drosophila melanogaster, is capable of detecting a vast range of genetic abnormalities, such as mutations, deletions and somatic recombinations (Graf et al., 1984; Würgler et al., 1984). During the embryonic development of $D$. melanogaster, imaginal disc-cell groups proliferate mitotically during larvae growth, until reaching the point of differentiating during metamorphosis of body structures of the adult insect. If genetic alteration occurs in any one of the imaginal disc cells, these changes will be present in all the following cells, subsequently forming a mutant cell clone. This being the case, mutant cells will be detected as a spot of mutant trichome on adult insects' wings (Guzmán-Rincón and Graf, 1995).

The drug doxorubicin (DXR) is capable of creating a variety of free radicals in cells, this capability being considered critical in its anti-tumoral effect (Keizer et al., 1990). The production of free radicals acts directly on the nucleus, thereby generating unfavorable conditions for cell division. This cytotoxic mechanism appears to be the principal antitumoral effect of DXR (Keizer et al., 1990). Doxorubicin is also the genotoxic agent that inhibits topoisomerase II activity, with the consequential accumulation of DNA strand breaks which, if not repaired by the cell, can provoke mutations and chromosomal aberrations (Islaih et al., 2005). In D. melanogaster, DXR, analyzed through SMART testing, was classified as a strong mutagen capable of inducing all types of spots (Frei et al., 1985).

Hence, the objective of the present study was to evaluate the genotoxic effects of LAP by applying the Drosophila melanogaster wing spot test. The influence of differences in the level of cytochrome P450 on LAP genotoxic activity were evaluated by way of standard (ST) and high-bioactivation (HB) crosses of Drosophila. An HB cross is characterized by an increased cytochrome P450dependent bioactivation capacity for promutagens when compared with an ST.

Each ampoule of the DXR commercially known as Adriblastina ${ }^{\circledR}$ RD (CAS 23214-92-8) (lot n ${ }^{\circ}$ G0421), manufactured by Pharmacia \& Upjohn S.p.A., Milan, Italy, and imported and distributed by Pharmacia of Brazil, Ltd., contains chlorohydrate of doxorubicin $(10 \mathrm{mg})$, methylpara- bene (1 mg) and lactose (50 mg), with Registry Number 1.2389.0046 in the Ministry of Health.

Lapachol (CAS 84-79-7) was provided by Dr. A. B. Oliveira (Federal University of Minas Gerais, Belo Horizonte, Minas Gerais, Brazil). The molecular structures of the test drugs are depicted in Figure 1. Solutions of these compounds were prepared with ethanol $5 \%$ just before use.

Three mutant strains of Drosophila melanogaster $\left(\mathrm{ORR}, \mathrm{flr}^{3}\right.$ and $\mathrm{mwh}$ ), with the genetic markers of multiple wing hairs (mwh, 3-0.3) and flare-3 (flr $\left.{ }^{3}, 3-38.8\right)$, were used.

Female virgins $\mathrm{flr}^{3} / \operatorname{In}(3$ LR)TM3, ri pp sep I(3) $89 \mathrm{Aa} \mathrm{bx}^{34 e}$ and $B d^{5}$ were crossed with $\mathrm{mwh} / \mathrm{mwh}$ males to produce the ST cross (Graf et al., 1989). The high metabolic bioactivation cross, with high constitutive levels of cytochrome P450 was the result of crossing the female virgins $O R R / O R R ; f l r^{3} / \operatorname{In}(3 L R) T M 3$, ri $p^{p}$ sep I(3) $89 A a b x^{34 e}$ and $B d^{s}$ with $m w h / m w h$ males (Graf and van Schaik 1992).

The resultant larvae of both genotypes were simultaneously treated with LAP, to facilitate future contact with the chemical agents to be tested. Larval descendents were collected over an $8 \mathrm{~h}$ period in culture jars containing a solid agar base (3\% of agar in water), with the addition of a layer of live baker's yeast (Sachcaromyces cerevisiae) and sugar. After three days $(72+8 \mathrm{~h})$, the larvae were washed out with tap water through a fine-mesh stainless steel strainer.

Larvae from both crosses were transferred to glass tubes, $2.5 \mathrm{~cm}$ in diameter and $8.0 \mathrm{~cm}$ high, each containing $1.5 \mathrm{~g}$ of instant mashed potatoes (HIKARI, Lot $\mathrm{n}^{\circ}$ L3068DD, São Paulo, Brazil) and 5.0 mL of LAP (20, 40 and $60 \mu \mathrm{g} / \mathrm{mL}$ ). The concentrations used in this experiment were based on studies of the lethal dose of lapachol in Aedes aegypti larvae (Rodrigues et al., 2005). DXR $(0.125 \mathrm{mg} / \mathrm{mL})$ constituted the positive control, whereas ethanol 5\% was used as the negative. As some compounds were photosensitive, all the tubes were wrapped in aluminum foil. Both control and treated larvae fed on the mashed potatoes until pupation $(48 \mathrm{~h})$.
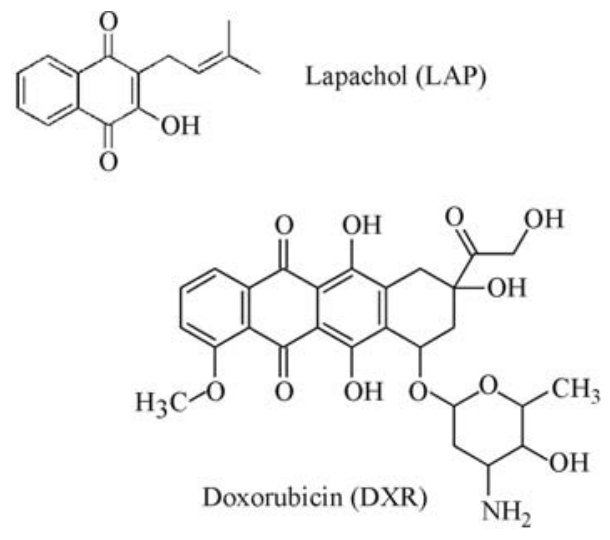

Figure 1 - Chemical structures of LAP and DXR. 
Each cross produce two types of progeny, that is, marker-heterozygous (MH) $\left(m w h \mathrm{flr}^{+} / \mathrm{mwh}^{+} \mathrm{flr}^{3}\right)$ and balancer-heterozygous (BH) $\left(m w h f l r^{+} / m w h^{+} T M 3, B d^{s}\right)$ flies, The dominant $B d^{5}$ marker allows the wings of these two genotypes to be distinguished.

The agents tested (LAP and DXR) were prepared in ethanol $5 \%$ when the larvae were treated. All experiments were performed at a temperature of $\left(25 \pm 2{ }^{\circ} \mathrm{C}\right)$ and at a humidity of $65 \%$. After hatching, the individual adults that emerged were transferred into a recipient containing $70 \%$ ethanol, and the wings were mounted on slides with Faure's solution, and analyzed under a compound microscope at 400x magnification (Graf et al., 1984). Frequency and the size of single and twin spots were recorded.

The statistical analysis of the experiment to verify possible genotoxic action of LAP was carried out using a test described by Frei and Würgler (1988), which makes four different diagnoses: positive, weakly positive, negative, or inconclusive. The frequency of each type of mutant clone per fly of a treated series was compared pairwise (i.e., control vs. LAP) using the conditional binomial test of Kastenbaum and Bowman (1970). For the final statistical analysis of all positive outcomes, the nonparametric Mann-Whitney $U$-test with significance levels $\alpha=\beta=0.05$ was used to exclude false positives (Frei and Würgler 1995).

All the compounds were tested in two different experiments. The data were pooled after verifying that the two independent experiments were in agreement with good reproducibility. Table 1 shows the frequency of mutant spots observed in the marker-heterozygous and balancerheterozygous descendants of ST cross and HB cross. Statistically, significant elevation was not observed $(p>0.05)$ on the frequencies of the spots induced by Lapachol (LAP) in the ST cross, in the three treated doses, when compared to the negative control group, in all the categories of spots. On the contrary, there was a positive response in HB descendents, with increased frequency of small single and total

Table 1 - Summary of results in the Drosophila SMART assay after treatment with Lapachol (LAP). Larvae from Standard (ST) cross and High Bioactivation (HB) cross.

\begin{tabular}{|c|c|c|c|c|c|c|c|c|c|c|}
\hline \multirow[b]{3}{*}{$\begin{array}{c}\mathrm{DXR} \\
(\mathrm{mg} / \mathrm{mL})\end{array}$} & \multirow[b]{3}{*}{$\begin{array}{c}\text { LAP } \\
(\mu \mathrm{g} / \mathrm{mL})\end{array}$} & \multicolumn{5}{|c|}{ Spots per fly $\left(\mathrm{N}^{\mathrm{o}}\right.$ of spots); stat. diagnoses ${ }^{\mathrm{a}}$} & \multirow{3}{*}{$\begin{array}{l}\text { Spots with } \\
m w h \text { clone }^{\mathrm{c}}\end{array}$} & \multirow{3}{*}{$\begin{array}{l}\text { Mean clone } \\
\text { size class }\end{array}$} & \multirow{2}{*}{\multicolumn{2}{|c|}{$\begin{array}{l}\text { Frequency of clone for } \\
\text { mation per } 10^{5} \text { cells }{ }^{\mathrm{d}}\end{array}$}} \\
\hline & & \multirow[b]{2}{*}{$\mathrm{N}^{\mathrm{o}}$ of flies } & \multirow{2}{*}{$\begin{array}{l}\text { Small single spots } \\
\qquad(1-2 \text { cells })^{\mathrm{b}}\end{array}$} & \multirow{2}{*}{$\begin{array}{c}\text { Large single } \\
\text { spots } \\
(>2 \text { cells })^{\mathrm{b}}\end{array}$} & \multirow[t]{2}{*}{ Twin } & \multirow[t]{2}{*}{ Total spots } & & & & \\
\hline & & & & & & & & & Observed & $\begin{array}{c}\text { Control } \\
\text { corrected }\end{array}$ \\
\hline \multicolumn{11}{|c|}{$\begin{array}{l}\text { ST cross } \\
m w h / f l r^{3}\end{array}$} \\
\hline 0 & 0 & 50 & $0.44(22)$ & $0.08(04)$ & $0.00(00)$ & $0.52(26)$ & 26 & 1.88 & 1.07 & \\
\hline 0.125 & 0 & 50 & $0.84(42)+$ & $0.52(26)+$ & $0.52(26)+$ & $1.88(94)+$ & 68 & 2.49 & 2.79 & 2.86 \\
\hline 0 & 20 & 60 & $0.52(31)-$ & $0.08(05) \mathrm{i}$ & $0.00(00) \mathrm{i}$ & $0.60(36)-$ & 36 & 1.83 & 1.23 & 0.16 \\
\hline 0 & 40 & 60 & $0.32(19)-$ & $0.07(04) \mathrm{i}$ & $0.02(01) \mathrm{i}$ & $0.40(24)-$ & 23 & 2.04 & 0.79 & -0.28 \\
\hline 0 & 60 & 60 & $0.35(21)-$ & $0.10(06) \mathrm{i}$ & $0.03(02) \mathrm{i}$ & $0.48(29)-$ & 27 & 2.11 & 0.92 & -0.14 \\
\hline \multicolumn{11}{|c|}{$m w h / T M 3$} \\
\hline 0 & 0 & 50 & $0.04(02)$ & $0.04(02)$ & & $0.08(04)$ & 4 & 2.00 & 0.16 & \\
\hline 0.125 & 0 & 50 & $0.10(05) \mathrm{i}$ & $0.06(03) \mathrm{i}$ & & $0.16(08) \mathrm{i}$ & 8 & 2.50 & 0.33 & 0.16 \\
\hline \multicolumn{11}{|c|}{$\begin{array}{l}\text { HB cross } \\
m w h / f l r^{3}\end{array}$} \\
\hline 0 & 0 & 50 & $0.62(31)$ & $0.04(02)$ & $0.04(02)$ & $0.70(35)$ & 33 & 1.64 & 1.35 & \\
\hline 0.125 & 0 & 50 & $2.04(102)+$ & $0.22(11)+$ & $0.32(16)+$ & $\begin{array}{c}2.58(129) \\
+\end{array}$ & 113 & 1.64 & 4.63 & 3.28 \\
\hline 0 & 20 & 60 & $0.93(56)+$ & $0.10(06) \mathrm{i}$ & $0.02(01) \mathrm{i}$ & $1.05(63)+$ & 62 & 1.55 & 2.12 & 0.77 \\
\hline 0 & 40 & 60 & $1.08(65)+$ & $0.13(08) \mathrm{i}$ & $0.07(04) \mathrm{i}$ & $1.28(77)+$ & 73 & 1.70 & 2.49 & 1.14 \\
\hline 0 & 60 & 60 & $1.25(75)+$ & $0.10(06) \mathrm{i}$ & $0.05(03) \mathrm{i}$ & $1.40(84)+$ & 81 & 1.54 & 2.77 & 1.41 \\
\hline \multicolumn{11}{|c|}{$m w h / T M 3$} \\
\hline 0 & 0 & 50 & $0.44(22)$ & $0.08(04)$ & & $0.52(26)$ & 26 & 1.58 & 1.07 & \\
\hline 0.125 & 0 & 50 & $0.44(22)-$ & $0.04(02) \mathrm{i}$ & & $0.48(24)-$ & 24 & 1.46 & 0.98 & -0.08 \\
\hline 0 & 20 & 50 & $0.30(15)-$ & $0.04(02) \mathrm{i}$ & & $0.34(17)-$ & 17 & 1.29 & 0.70 & -0.37 \\
\hline 0 & 40 & 50 & $0.40(20)-$ & $0.02(01)-$ & & $0.42(21)-$ & 21 & 1.48 & 0.86 & -0.20 \\
\hline 0 & 60 & 50 & $0.40(20)-$ & $0.00(00)-$ & & $0.40(20)-$ & 20 & 1.20 & 0.82 & -0.25 \\
\hline
\end{tabular}

${ }^{\text {a}}$ Statistical diagnoses according to Frei and Würgler (1988): +, positive; -, negative; i, inconclusive; m, multiplication factor. Kastenbaum-Bowman tests, one sided. Probability levels $\alpha=\beta=0.05$. ${ }^{\mathrm{b}}$ Including rare $f l r^{3}$ single spots. ${ }^{\mathrm{c}}$ Considering $m w h$ clones from $m w h$ single and twin spots. ${ }^{\mathrm{d}} \mathrm{Frequency}$ of clone formation: clones/flies/48,800 cells (without size correction). DXR, doxorubicin; LAP, lapachol. 
spots (for 20, 40 and $60 \mu \mathrm{g} / \mathrm{mL}$ LAP). DXR produced a positive response in both ST and HB descendants, thereby confirming its genotoxicity.

Sousa et al. (2009) showed that a commercial preparation of the powdered bark and stem of Tabebuia impetiginosa, although toxic, did not induce somatic mutation and recombination in D. melanogaster from ST and HB crossbreeding. The absence of genotoxicity, in this case, could be due to the low concentration of lapachol in exposed larvae. However, these authors indicated that powdered bark and stem of $T$. impetiginosa possess a considerable potentiating effect on DXR genotoxicity.

The analysis of flies with genotype $m w h / T M 3$ was carried out for the purpose of calculating the portion of recombinogenic and mutagenic events. It is possible to separate mutational events from recombinational events, because the recombinational events are eliminated in flies with this genotype. A comparison of clone-induction frequencies obtained for DXR in both genotypes indicated that in ST flies, $12 \%$ of mutant clones produced by DXR were due to mutation and $88 \%$ to recombination. Furthermore, the very same analysis showed that in HB flies, $21 \%$ of spots induced by DXR were due to mutation, and $79 \%$ to recombination. The strong recombinogenic activity of DXR in somatic cells of D. melanogaster was earlier reported by Lehmann et al. (2003), Costa and Nepomuceno (2006) and Fragiorge et al. (2007). Our results indicated that recombinogenicity is the major genotoxic effect of LAP $20 \mu \mathrm{g} / \mathrm{mL}$ (approximately 67\% through recombination), LAP $40 \mu \mathrm{g} / \mathrm{mL}$ (approximately $65.5 \%$ recombination) and LAP $60 \mu \mathrm{g} / \mathrm{mL}$ (approximately $70 \%$ recombination). There are no published articles on LAP genotoxicity, and the mutagenicity of this chemical was only studied on the Ames test (Krishnan and Bastow, 2000). On the other hand, mitotic recombinogenic activity had neither been demonstrated nor otherwise quantified. This recombinogenic activity is demonstrated in this study and also found in DXR (another quinone), which again shows similarities in the effects of these drugs.

Numerous quinones play vital roles in the biochemistry of living cells, and exert relevant biological activities. The cytostatic and antimicrobial activities of these quinones emerge by virtue of their ability to act as potential inhibitors of electron transport, as uncouplers of oxidative phosphorylation, as DNA intercalating agents, as bioreductive alkylating agents, and as producers of reactive oxygen radicals by redox cycling under aerobic conditions (Lima et al., 2002).

The main LAP toxicity attribute is its capacity to induce oxidative stress (Silva et al., 2003). It has been demonstrated (Kumagai et al., 1997; Kumagai and Shimojo, 2002) that oxidative stress induced by LAP occurs as a response to P450 reductase enzyme activities, thereby causing changes in the DNA. LAP itself has no direct effect on DNA, although, as can be observed, this is not so when it interacts with cytochrome P450. Similar results were obtained in our study that showed an increase in the frequencies of the mutant spots induced by LAP in descendants from HB cross. DNA changes require bioactivation as processed by cytochrome P450 reductase (CPR), a diflavin enzyme (Kumagai et al., 1997). Shiah et al. (1999) were able to demonstrate that beta-lapachone (a semi- synthetic derivate of LAP) is capable of increasing the levels of $\mathrm{H}_{2} \mathrm{O}_{2}$ and $\mathrm{O}_{2}{ }^{-}$(oxidative stress) in leukemia cells of HL-60, thus inducing apoptosis in the later stages. They also showed that induced apoptosis can be related or linked to increased cell $\mathrm{H}_{2} \mathrm{O}_{2}$ levels when activated by NAD (P)H/ quinone oxidoreductase.

Quinones are used as a chemotherapy agent since they act much like LAP. Doxorubicin (DXR) is capable of producing a series of free radicals in the cell (Keizer et al., 1990). These free radicals produced by DXR act directly on the nucleus, generating unfavorable conditions for cell division (multiplication). This cytotoxic mechanism is one of the agents responsible for the anticancer effects of DXR (Keizer et al., 1990). The DXR requires a metabolic reduction of the quinone ring for the semiquinone radical to produce a toxic effect (Ramji et al., 2003).

On the other hand, Krishnan and Bastow (2000) also indicated that LAP was involved in interference with the normal function of topoisomerase II (topo II) enzyme. Esteves-Souza et al. (2007) showed the inhibitory effects of human DNA-topoisomerase II-a by LAP amine derivatives. According to Esteves-Souza et al. (2007) the inhibitory action on DNA-topoisomerase II-a was also evaluated by a relaxation assay of supercoiled DNA plasmid. A significant inhibitory action of the enzyme was observed, and greater activity on the part of LAP amine derivatives than the corresponding lawsone derivatives. Cunha et al. (2006) showed that $2 \mu \mathrm{M}$ of lapachol derivatives significantly hindered topo II-a catalytic activity. This interference in the DNA-Topo II-drug complex may produce a DNA topology that favors the occurrence of recombinational events (Baguley and Ferguson, 1998). Lehmann et al. (2003) attributed homologous recombination induced by DXR to a similar mechanism.

Although homologous recombination is an important pathway in DNA repair, there is growing evidence that deleterious genomic rearrangements may result from homologous recombination, which means that homologous recombination events may play a causative role in carcinogenesis (Arossi et al., 2009). The transformation of normal cells into cancer cells is a multistep process, with mitotic recombination as a mechanism involved in bringing about such transformation (Nowell, 1976; Barrett, 1993). In heterozygous cells, bearing a mutant and normal alleles for a tumor suppressor gene, the somatic recombination may turn up to be a promoter of neoplasms by inducing homozygosis of the mutant tumor suppressor, allele (Maher et al., 1993; Sengstag, 1994). 
It can be said that LAP, a quinone belonging to the naphthoquinone group, under the experimental conditions mentioned in this study is genotoxically active through recombination, as verified by wing-spot test of Drosophila melanogaster. This genotoxicity was only observed in descendants of the crossing of high metabolic bioactivation (HB). These results demonstrate that LAP, in the analyzed concentration, is an indirect genotoxic agent, thus indicating the need for metabolic bioactivation by the cytochrome P450 enzyme.

\section{Acknowledgments}

This study was funded by the Brazilian agencies CNPq, CAPES, and FAPEMIG under the auspices of the Universidade Federal de Uberlândia and Centro Universitário de Patos de Minas.

\section{References}

Arossi GA, Dih RR, Lehmann M, Cunha KS, Reguly ML and Andrade HHR (2009) In vivo genotoxicity of dental bonding agents. Mutagenesis 24:169-172.

Baguley BC and Ferguson LR (1998) Mutagenic properties of topoisomerase-targeted drugs. Biochim Biophys Acta 1400:213-222.

Barrett JC (1993) Mechanisms of multistep carcinogenesis and carcinogen risk assessment. Environ Health Perspect 100:9-12.

Castellanos JRG, Prieto JM and Heinrich M (2009) Red Lapacho (Tabebuia impetiginosa) - A global ethnopharmacological commodity? J Ethnopharmacol 121:1-13.

Costa WF and Nepomuceno JC (2006) Protective effects of a mixture of antioxidant vitamins and mineral on the genotoxicity of doxorubicin in somatic cells of Drosophila melanogaster. Environ Mol Mutagen 47:18-24.

Cunha AS, Lima ELS, Pinto AC, Esteves-Souza A, Echevarria A, Camara CA, Vargas MD and Torres JC (2006) Synthesis of novel naphthoquinone-spermidine conjugates and their effects on DNA-topoisomerases I and II-a. J Braz Chem Soc 17:439-442.

Dinnen RD and Ebisuzaki K (1997) The search for novel anticancer agents: A differentiation-based assay and analysis of a folklore product. Anticancer Res 17:1027-1033.

Esteves-Souza A, Figueiredo DV, Esteves A, Câmara CA, Vargas MD, Pinto AC and Echevarria A (2007) Cytotoxic and DNA-topoisomerase effects of lapachol amine derivatives and interactions with DNA. Braz J Med Biol Res 40:13991402.

Fonseca SGC, Silva LBL, Castro RF and Santana DP (2004) Validação de metodologia analítica para doseamento de soluções de lapachol por clae. Quim Nova 27:157-159.

Fragiorge EJ, Spanó MA and Antunes LMG (2007) Modulatory effects of the antioxidant ascorbic acid on the direct genotoxicity of doxorubicin in somatic cells of Drosophila melanogaster. Genet Mol Biol 30:449-455.

Frei H, Würgler FE, Juon H, Hall CB and Graf U (1985) Aristolochic acid is mutagenic and recombinogenic in Drosophila genotoxicity tests. Arch Toxicol 56:158-166.
Frei H and Würgler FE (1988) Statistical methods to decide whether mutagenicity test data from Drosophila assays indicate a positive, negative, or inconclusive result. Mutat Res 203:297-308.

Frei H and Würgler FE (1995) Optimal experimental design and sample size for the statistical evaluation of data from somatic mutation and recombination test (SMART) in Drosophila. Mutat Res 334:247-258.

Graf U and van Schaik N (1992) Improved high bioactivation cross for the wing somatic mutation and recombination test in Drosophila melanogaster. Mutat Res 271:59-67.

Graf U, Würgler FE, Katz AJ, Frei H, Juon H, Hall CB and Kale PG (1984) Somatic mutation and recombination test in Drosophila melanogaster. Environ Mutagen 6:153-188.

Graf U, Frei H, Kägi A, Katz AJ and Würgler FE (1989) Thirty compounds tested in the Drosophila wing spot test. Mutat Res 222:359-373.

Guzmán-Rincón J and Graf U (1995) Drosophila melanogaster somatic mutation and recombination test as a biomonitor. In: Biomonitors and Biomarkers as Indicators of Environmental Change. New York, Phenum Press, pp 169-181.

Islaih M, Halstead BW, Kadura IA, Li B, Reid-Hubbard JL, Flick L and Altizer JL (2005) Relationships between genomic, cell cycle, and mutagenic responses of TK6 cells exposed to DNA damaging chemicals. Mutat Res 578:100-116.

Kastenbaum MA and Bowman KO (1970) Tables for determining the statistical significance of mutation frequencies. Mutat Res 9:527-549.

Keizer HG, Pinedo HM, Schuurhuis GJ and Joenje H (1990) Doxorubicin (adriamycin): A critical review of free radical-dependent mechanisms of cytotoxicity. Pharmacol Ther 47:219-231.

Krishnan P and Bastow KF (2000) Novel mechanisms of DNA topoisomerase II inhibition by pyranonaphthoquinone derivatives-eleutherin, alpha lapachone, and beta lapachone. Biochem Pharmacol 60:1367-1379.

Kumagai Y and Shimojo N (2002) Possible mechanisms for induction of oxidative stress and suppression of systemic nitric oxide production caused by exposure to environmental chemicals. Environ Health Prev Med 7:141-150.

Kumagai Y, Tsurutani Y, Shinyashiki M, Takeda SH, Nakai Y, Yoskikawa T and Shimojo N (1997) Bioactivation of lapachol responsible for DNA scission by NADPHcytochrome P450 reductase. Environ Toxicol Pharmacol 3:245-250.

Lehmann M, Franco A, Souza Prudente Vilar K, Luíza-Reguly M and Andrade HHR (2003) Doxorubicin and two of its analogues are preferential inducers of homologous recombination compared with mutational events in somatic cells of Drosophila melanogaster. Mutat Res 539:167-175.

Lima NMF, Santos AF, Porfírio Z, Goulart MOF and Sant'ana AEG (2002) Toxicity of lapachol and isolapachol and their potassium salts against Biomphalaria glabrata, Schistosoma mansoni cercariae, Artemia salina and Tilapia nilotica. Acta Trop 83:43-47.

Lima NMF, Correia CS, Leon LL, Machado GMC, Madeira MF, Santana AEG and Goulart MOF (2004) Antileishmanial activity of lapachol analogues. Mem Inst Oswaldo Cruz 99:757-761.

Maher VM, Bhattacharyya NP, Mah MC, Boldt J, Yang JL and Mccormick JJ (1993) Mutations induced by 1-nitrosopyrene and related compounds during DNA replication in human 
cells and induction of homologous recombination by these compounds. Res Rep Health Eff Inst 40:41-51.

Nowell P (1976) The clonal evaluation of tumour cell populations. Science 194:23-28.

Ramji S, Lee C, Inaba T, Patterson AV and Riddick DS (2003) Human NADPH-cytochrome P-450 reductase overexpression does not enhance the aerobic cytotoxicity of doxorubicin in human breast cancer cell lines. Cancer Res 63:6914-6919.

Rao KV, McBride TJ and Oleson JJ (1968) Recognition and evaluation of lapachol as an antitumor agent. Cancer Res 28:1952-1954.

Rodrigues AMS, de Paula JE, Roblot F, Fournet A and Espíndola LS (2005) Larvicidal activity of Cybistax antisyphilitica against Aedes aegypti larvae. Fitoterapia 76:755-757.

Santos AF, Ferraz PAL, Pinto AV, Pinto MCRF, Goulart MOF and Sant'Ana AEG (2000) Molluscicidal activity of 2-hydroxy-3-alkyl-1,4-naphthoquinones and derivatives. Int $\mathbf{J}$ Parasitol 30:1199-1202.

Sengstag C (1994) The role of mitotic recombination in carcinogenesis. Crit Rev Toxicol 24:323-353.

Shiah SG, Chuang SE, Chau YP, Shen SC and Kuo ML (1999) Activation of c-Jun NH2-terminal kinase and subsequent CPP32/Yama during topoisomerase inhibitor $\beta$-lapachoneinduced apoptosis through an oxidation-dependent pathway. Cancer Res 59:391-398.

Silva AJM, Buarque CD, Brito FV, Aurelian L, Macedo LF, Malkas LH, Hickey RJ, Lopes DVS, Noel F, Murakami YLB et al. (2002) Synthesis and preliminary pharmacological evaluation of new $( \pm)$ 1,4-naphthoquinones structurally related to lapachol. Bioorg Med Chem 10:2731-2738.
Silva MN, Ferreira VF and Souza CBV (2003) Um panorama atual da química e da farmacologia de naftoquinonas, com ênfase na $ß$-lapachona e derivados. Quim Nova 26:407-416.

Sousa NC, Rezende AAA, Silva RMG, Guterres ZR, Graf U, Kerr WE and Spanó MA (2009) Modulatory effects of Tabebuia impetiginosa (Lamiales, Bignoniaceae) on doxorubicininduced somatic mutation and recombination in Drosophila melanogaster. Genet Mol Biol 32:382-388.

Suffness M and Douros J (1980) Miscellaneous natural products with antitumor activity. In: JM Cassady and JD Douros (eds) Anticancer Agents Based on Natural Product Models. Academic Press, New York, pp 465-487.

Vieira RF and Martins MVM (1998) Estudos etnobotânicos de espécies medicinais de uso popular no Cerrado. In: Proc Int Savanna Simposium. Embrapa/CPAC, Brasilia, pp 169-171.

Würgler FE, Sobels FH and Vogel E (1984) Drosophila as an assay system for detecting genetic changes. In: Handbook of Mutagenicity Test Procedure. Elsevier, Amsterdam, pp 555-601.

\section{Internet Resources}

Vieira RF (1999) Conservation of Medicinal and Aromatic Plants in Brazil, http://www.hort.purdue.edu/newcrop/proceedings 1999/v4152.html (August 2, 2008).

Associate Editor: Catarina S. Takahashi

License information: This is an open-access article distributed under the terms of the Creative Commons Attribution License, which permits unrestricted use, distribution, and reproduction in any medium, provided the original work is properly cited. 